Provided for non-commercial research and education use. Not for reproduction, distribution or commercial use.

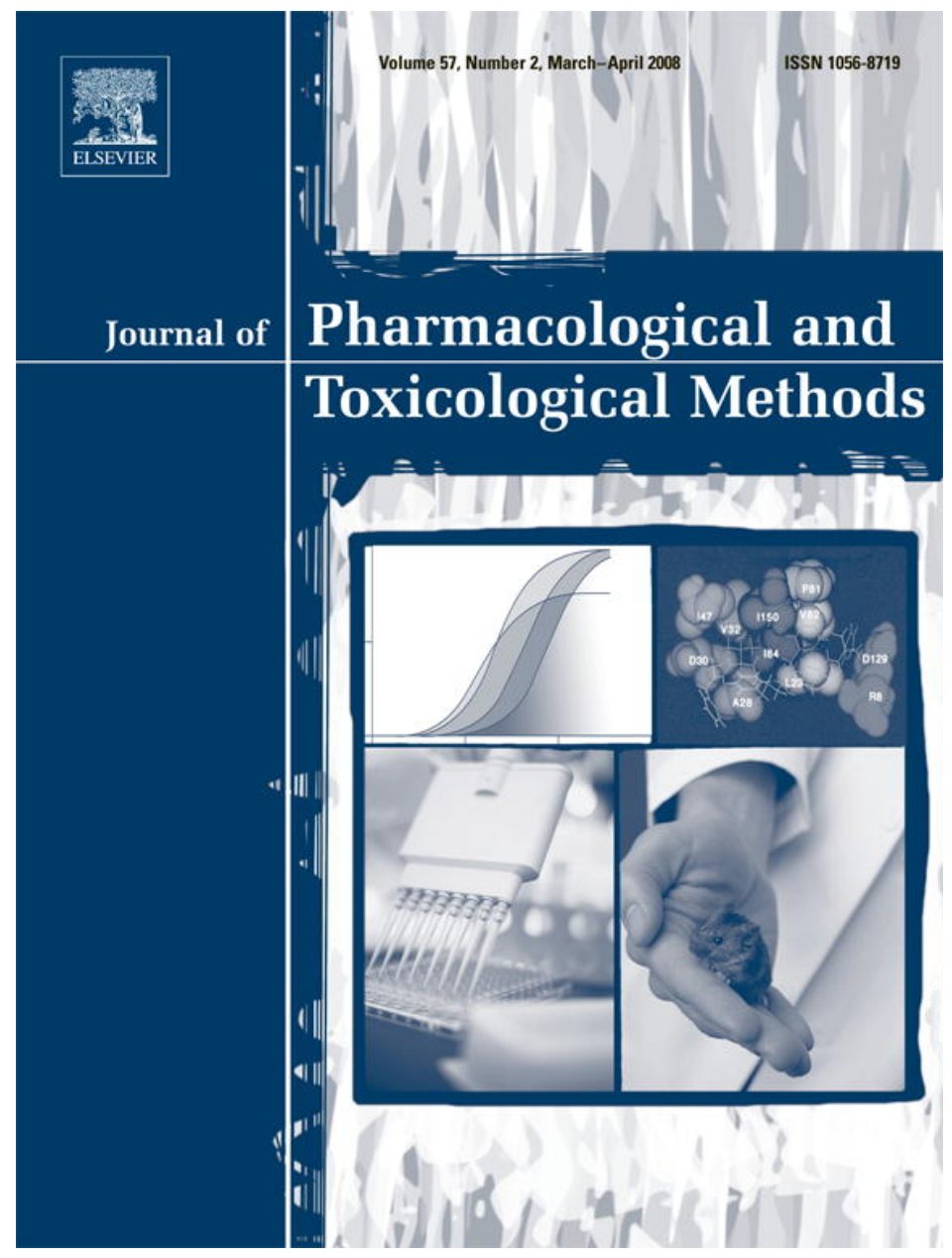

This article was published in an Elsevier journal. The attached copy

is furnished to the author for non-commercial research and education use, including for instruction at the author's institution, sharing with colleagues and providing to institution administration.

Other uses, including reproduction and distribution, or selling or licensing copies, or posting to personal, institutional or third party websites are prohibited.

In most cases authors are permitted to post their version of the article (e.g. in Word or Tex form) to their personal website or institutional repository. Authors requiring further information regarding Elsevier's archiving and manuscript policies are encouraged to visit: 


\title{
Gene and protein expression changes in response to normoxic perfusion in mouse hearts
}

\author{
Nóra Faragó $^{\mathrm{a}}$, Gabriella F. Kocsis ${ }^{\mathrm{b}}$, Liliána Z. Fehér ${ }^{\mathrm{a}}$, Tamás Csont ${ }^{\mathrm{b}}$, László Hackler Jr. ${ }^{\mathrm{a}}$, \\ Zoltán Varga-Orvos ${ }^{\mathrm{a}}$, Csaba Csonka ${ }^{\mathrm{b}}$, János Z. Kelemen ${ }^{\mathrm{a}}$, Péter Ferdinandy ${ }^{\mathrm{b}}$, László G. Puskás ${ }^{\mathrm{a}, *}$ \\ ${ }^{a}$ Laboratory of Functional Genomics, Biological Research Center, Hungarian Academy of Sciences, H-6726, Szeged, Hungary \\ ${ }^{\mathrm{b}}$ Cardiovascular Research Group and Pharmahungary Group, Department of Biochemistry, University of Szeged, H-6720, Szeged, Hungary
}

Received 28 September 2007; accepted 12 January 2008

\begin{abstract}
Introduction: Although crystalloid-perfused isolated heart models are widely used in cardiovascular research, there are several limitations of these techniques. Changes in cardiac gene expression pattern due to normoxic perfusion itself have not been studied, despite its potential importance to provide useful information on limitations of this model. Therefore, here we investigated the time-dependent effect of normoxic, normothermic perfusion on global gene expression at mRNA and protein levels. Methods: Hearts from male CFLP mice were perfused according to the Langendorff technique. We assessed relative gene expression changes by DNA microarray analysis of 8000 genes after 0,60 and 120 min perfusion. Results: Twelve genes exhibited significant up-regulation and 27 showed repression in hearts perfused for 60 or 120 min as compared to 0 min controls. Expression changes of 17 selected genes were verified and an additional 19 genes were examined by real-time quantitative PCR. Genes with altered expression included those coding for Creatin kinase, Lactate dehydrogenase, Voltage-dependent anion channel 1, a Disintegrin and Metalloprotease domain 3, Integrin alpha 7, Long-chain acyl-CoA dehydrogenase, Casein kinase II, Ketohexokinase, Chloride ion current inducer protein, Matrix metalloproteinase 2 and 9, Superoxide dismutases and Nitric oxide synthases, etc. Discussion: Our results show that normoxic crystalloid perfusion itself results in time-dependent changes in cardiac gene expression which should be considered when designing ex vivo perfusion protocols in the mouse heart to mimic cardiac pathologies as many of these genes have been suspected to influence several cardiovascular diseases.
\end{abstract}

(C) 2008 Elsevier Inc. All rights reserved.

Keywords: Normoxic perfusion; Isolated heart; Global gene expression; Heart model; Mouse heart

\section{Introduction}

The isolated perfused heart is one of the most widely used experimental models in cardiovascular research, including testing drug efficacy and safety and modeling cardiovascular

\footnotetext{
* Corresponding author. Postal address: Laboratory of Functional Genomics, Biological Research Center, Hungarian Academy of Sciences, Temesvári krt. 62, H-6726, Szeged, Hungary. Tel.: +36 62/599 782; fax: +36 62/432 576.

E-mail address: pusi@brc.hu (L.G. Puskás).

URL's: http://www.cardiovasc.com (G.F. Kocsis),

http://www.cardiovasc.com (T. Csont), http://www.cardiovasc.com (C. Csonka), http://www.cardiovasc.com (P. Ferdinandy).
}

pathologies such as ischemia-reperfusion injury. It is a relatively simple model and it provides a highly reproducible preparation which can be used for comprehensive examinations of cardiac contractile function, electrophysiology, cellular biochemistry and molecular biology. However, the major limitations of this model include deterioration of myocardial function within beyond $60 \mathrm{~min}$ possibly due to oxidative and nitrosative stress (Ferdinandy, Panas, \& Schulz, 1999) and unusual appearance of cardiac arrhythmias (Clements-Jewery, Hearse, \& Curtis, 2002; Curtis, 1998; Hearse, Richard, Yellon, \& Kingma, 1988; Miyashita et al., 2000; Ravingerova, Pancza, Ziegelhoffer, \& Styk, 2005; Schomisch et al., 2005). Although the most frequently used ex vivo heart preparation is the rat heart, due to the lower cost and the appearance of the genetically modified 
mice, ex vivo mice heart preparations have been rapidly spreading in the scientific community.

Unfortunately, although the literature contains an increasing number of studies employing mouse hearts, the fundamental characteristics of that have yet to be completely characterized (Sutherland \& Hearse, 2000). In our study we used isolated and perfused mouse hearts. Hearts were excised, mounted on the Langendorff apparatus and perfused. Despite of several studies employing Langendorff perfusion in rat hearts (Onody et al., 2003; Puskás et al., 2004), still very little is known about the gene expression pattern of the heart in response to ischemiareperfusion after different periods of time. Without the knowledge of gene expression changes at mRNA and protein levels in the perfused heart, it is difficult to define specific controls and these variations could alter the results of different studies. Therefore we have tried to answer such questions as: what are the effects of oxygenated perfusion fluid on global gene expression and how does it change related to time. To profile gene expression patterns at mRNA level, we monitored global gene expression changes by DNA microarray analysis (Onody et al., 2003) and validated the results by quantitative real-time polymerase chain reaction (QRT-PCR) in the mouse hearts. We studied the importance of perfusion time. The effects of 60 and 120 min perfusion were also studied and transcriptional changes were evaluated. Furthermore, two enzyme-activity measurements for lactate dehydrogenase and creatine kinase activities were investigated.

\section{Materials and methods}

\subsection{Perfusion protocol of isolated mouse hearts}

Male CFLP mice (35-45 g) were anesthetized with diethylether and given $150 \mathrm{U}$ heparin ip. Hearts were then isolated and perfused in Langendorff mode (at a constant pressure of $70 \mathrm{~mm} \mathrm{Hg}, 37^{\circ} \mathrm{C}$ ) with Krebs-Henseleit buffer containing (in mmol/L) $118 \mathrm{NaCl}, 25 \mathrm{NaHCO}_{3}, 4.7 \mathrm{KCl}, 1.2$ $\mathrm{MgSO}_{4}, 1.2 \mathrm{KH}_{2} \mathrm{PO}_{4}, 1.75 \mathrm{CaCl}_{2}$, and 11.1 glucose, oxygenated with $95 \% \mathrm{O}_{2}-5 \% \mathrm{CO}_{2}(\mathrm{pH}=7.4)$ as described (Csont et al., 2005; Giricz, Csonka, Onody, \& Csont, 2003). To investigate the effect of the extent of ex vivo perfusion on the changes of gene expression pattern of mouse hearts three different perfusion protocols were applied $(n=5-8$ in each group). Hearts were subjected to either a $5 \mathrm{~min}$ wash out period, or a $60 \mathrm{~min}$ or $120 \mathrm{~min}$ normothermic, aerobic perfusion. Heart rate and coronary flow were monitored throughout the perfusion protocol in all groups. At the end of the perfusion protocol, hearts from all groups were frozen and crushed at the temperature of liquid nitrogen.

\section{2. $R N A$ isolation}

RNA was purified from each group (76-100 mg tissue from each heart) Samples were rotor-homogenized and treated with proteinase-K (Qiagen). Total RNA was extracted with RNeasy Fibrous Tissue Mini Kit (Qiagen) according to the manufacturer's instructions (Onody et al., 2003). Prepared RNA samples from each group were pooled, and their quantities and qualities were assessed spectrophotometrically. The same total RNA pool was used for microarray analysis and for QRT-PCR.

\subsection{Microarrays, sample preparations and hybridizations}

Construction and use of microarrays were performed as described previously (Puskás, Zvara, Hackler, Micsik \& van Hummelen, 2002). $2 \mu \mathrm{g}$ of total RNA was reverse transcribed (Fermentas, RevertAid H Minus M-MuLV Reverse Transcriptase) according to the manufacturer's instruction. cDNA with Cy5 capture sequence was hybridized onto mouse microarray containing 8000 mouse specific cDNA probes. All the other sample preparation steps were done according the manufacturer's instructions (Genisphere). Both the first step cDNA hybridization and the second step capture reagent hybridization were carried out in a Ventana hybridization station (Ventana Discovery, Tucson, AZ) by using the "antibody" protocol. First hybridization was performed at $40{ }^{\circ} \mathrm{C}$ for $6 \mathrm{~h}$ in "FGL2" hybridization buffer $(10 \times$ Denhardt's solution, $0.25 \mathrm{M}$ sodium phosphate buffer $\mathrm{pH} 7.0,1 \mathrm{mM}$ EDTA, $1 \times \mathrm{SSC}, 0.5 \% \mathrm{SDS})$, and then $2.5 \mu \mathrm{l}$ of each $\mathrm{Cy} 5$ and $\mathrm{Cy} 3$ capture reagents were added to the slides in $200 \mu 1$ "ChipHybe" hybridization buffer (Ventana) and incubated at $42{ }^{\circ} \mathrm{C}$ for $2 \mathrm{~h}$. After hybridization slides were washed in $0.2 \times \mathrm{SSC}$ twice at room temperature for $10 \mathrm{~min}$ and then dried and scanned.

\subsection{Scanning and data analysis}

Each array was scanned under a red laser (633 nm for Cy5 labeling) using a ScanArray Lite (GSI Lumonics, Billerica, MA) scanning confocal fluorescent scanner with $10 \mu \mathrm{m}$ resolution. Scanned output files were analyzed using GenePix Pro5.0 software (Axon Instruments Inc., Foster City, CA). Each spot was defined by automatic positioning of a grid of circles over the image. For each channel, the median values of feature and local background pixel intensities were determined (Palotas et al., 2004). The background corrected expression data were filtered for flagged spots and weak signals. Technical replicates on the same array were averaged. Data were excluded in cases where technical replicates were significantly different. Normalization was performed using the print-tip LOWESS method (Yang et al., 2002). Next, we used the one-sample $t$ test to determine the genes to be regarded as regulated in response to treatment. Logarithm was taken from each expression ratio to fulfill the requirement of the $t$ test for a normal distribution. Genes for which the mean of log ratios across the biological replicates were equal to zero at a significance level $(\alpha=0.05)$ are considered to have an unchanged expression. On the other hand, genes having a $p$ value smaller than $\alpha$ and the average fold change (increase or decrease) of the four data points were at least 1.9 times were considered as regulated genes.

\subsection{Quantitative real-time polymerase chain reaction (QRT-PCR)}

QRT-PCR was performed on a RotorGene 3000 instrument (Corbett Research, Sydney, Australia) with gene-specific 
primers and SybrGreen protocol to confirm expression changes of 17 selected genes observed by microarrays. An additional 19 genes strongly related to cardiac stress adaptation and ischemia/ reperfusion injury, but not available on the microarray were also investigated by QRT-PCR.

Two $\mu \mathrm{g}$ of total RNA from each sample were reverse transcribed in the presence of random primers in a total volume of $20 \mu \mathrm{l}$. After dilution with $20 \mu \mathrm{l}$ of water, $1 \mu \mathrm{l}$ of the diluted reaction mix was used as template in QRT-PCR. The $20 \mu \mathrm{l}$ reaction volume contained $0.2 \mathrm{mM}$ of $\mathrm{dNTP}, 1 \times \mathrm{PCR}$ reaction buffer (ABGene, Epsom, UK), $6 \mathrm{mM}$ of each primer, $4 \mathrm{mM}$ of $\mathrm{MgCl}_{2}, 1 \times \mathrm{SYBR}$ Green I (Molecular Probes, Eugene, OR) at final concentration, and $0.5 \mathrm{U}$ of thermostart Taq DNA polymerase (ABGene). Amplification was carried out with the following cycling parameters: $600 \mathrm{~s}$ heat start at $95^{\circ} \mathrm{C}, 45$ cycles of denaturation at $95^{\circ} \mathrm{C}$ for $25 \mathrm{~s}$, annealing at $60{ }^{\circ} \mathrm{C}$ for $25 \mathrm{~s}$, and fluorescence detection at $72{ }^{\circ} \mathrm{C}$ for $15 \mathrm{~s}$. After amplification, a melting curve was created to verify the specificity of PCR reactions. Relative expression ratios were normalized to GAPDH, as a widely used housekeeping gene. The PCR primers used in this study are listed in Table 1.

\subsection{Myocardial lactate dehydrogenase (LDH) and creatine kinase (CK) activities}

In order to further investigate whether changes in cardiac gene expression due to differences in ex vivo perfusion time leads to alterations at the protein level enzyme activities of LDH and CK were determined from cardiac tissue. Ventricular tissue was homogenized as described previously (Gao et al., 2003). Both LDH and CK activities were determined by a spectrophotometric kinetic analysis at $340 \mathrm{~nm}$ using commercially available diagnostic kits (Diagnosticum Rt., Budapest, Hungary) according to the instructions of the manufacturer. Enzyme activities were normalized to the total protein content of the homogenates and expressed as $\mathrm{mU} / \mathrm{mg}$ protein.

\section{Results}

\subsection{Gene expression alteration due to perfusion}

Using DNA microarray technology, we analyzed 8000 genes for changes in expression associated with the perfusion related to incubation time. Relative gene expression changes in mouse hearts in response to 60 and 120 min perfusion were compared to the expression profile of the control animals. Among the 8000 genes examined in the present study 39 genes showed altered expression. We selected 17 genes (Table 1) of which the expression were significantly altered in the heart due to 60 or 120 min perfusion for QRT-PCR analysis. Out of these, two genes exhibited significant up-regulation and 15 were downregulated (Table 2).

Gene coding for Glucosaminyl- $N$-deacetylase/ $N$-sulfotransferase 2 (Ndst2), responsible for HS $N$-sulfation was repressed after 60 and 120 min of perfusion.

Another gene related to glycosphingolipid biosynthesis was also repressed: beta-1,4- $N$-acetyl-galactosaminyl transferase 1 with a 1.52 fold repression after 60 min of perfusion.

Perfusion altered the expression of three genes having a role in the regulation of cell cycle. Casein kinase II was overexpressed after $60 \mathrm{~min}$, however, QRT-PCR analysis could not confirm this induction. After $120 \mathrm{~min}$, changes were normalized to control level both in microarray and QRT-PCR.

Changes in the expression of other cell cycle regulatory genes showed repression, which was also confirmed by QRT-PCR. $\mathrm{G}$ two $\mathrm{S}$ phase expressed protein 1 (previously named as B99) had only shown down-regulation after $120 \mathrm{~min}$ of perfusion. The expression of Ketohexokinase (Khk) was significantly declined after 60 and also $120 \mathrm{~min}$ of perfusion.

A key enzyme of the glycolysis, Lactate dehydrogenase A-4 was down-regulated in response to perfusion.

Gene coding for long-chain acyl-CoA dehydrogenase (LCAD) was significantly down-regulated after $2 \mathrm{~h}$ of perfusion.

Table 1

Primers used in quantitative real-time polymerase chain reaction (QRT-PCR) analysis

\begin{tabular}{|c|c|c|c|}
\hline Gene product & Accession number & Forward primer & Reverse primer \\
\hline$N$-deacetylase $/ N$-sulfotransferase & NM_010811 & TGATGACAAGAGGCACAAAGA & AAGAAGTGAATAGCCGTGGTG \\
\hline Beta-1,4- $N$-acetyl-galactosaminyl transferase 1 & NM_008080 & GCCAACACAGCAGACACAGT & GAGGATGGTGAAGGCAACTT \\
\hline $\mathrm{G}$ two $\mathrm{S}$ phase expressed protein 1 & NM_013882 & TTCACCTGGCTACAGAGAAGC & TCACGAGTTTCGTCCTCTGA \\
\hline Microtubule-associated protein 1 & NM_007896 & GTTCAGCCCCTGATGTGTTT & GGTCACAGGGAGCAGAGAGA \\
\hline Ketohexokinase & NM_008439 & CATCATCAATGTGGTGGACAA & TGCCATCTCTGGGACAGG \\
\hline Integral membrane protein $2 \mathrm{~B}$ & NM_008410 & CTGAACACTTCCATCGTTATGC & GGTAGGACTGAGGCAGGTAGG \\
\hline Casein kinase II, alpha 2 & NM_009974 & AAGTATAGTGAAGTATTTGAGGCCATT & TCGTTTTATCTTCTTTTTCTTCACTG \\
\hline A disintegrin and metalloprotease domain 3 & NM_009619 & GAAAATCGACACCAACATCCA & CCCTCAATTGTGACCACGTA \\
\hline Troponin $\mathrm{T} 1$ & NM_011618 & ATCTGTGGACCCAGCCTTAG & GCCTGCTCCTCCTCATATTCT \\
\hline Acetyl-Coenzyme A dehydrogenase, long-chain & NM_007381 & AAGTGATTCCTCACCACACAGA & CAGCTTTTTCCCAGACCTCTC \\
\hline Integrin alpha 7 & NM_008398 & AAGTGCCATGCGATCTGAG & GACTGGCCTTGATTGGAGAC \\
\hline Chloride ion current inducer protein & U53455 & TGAACCCATTTCTGAATTTCG & GTGAACATCGCCTCCAATG \\
\hline Protein phosphatase 1 inhibitor 14B & NM_008889 & CTCACGCGACTCTACGACTG & CCATGTCTAAAAGTTCATCCACA \\
\hline Interleukin 12 receptor, beta 1 & NM_008353 & CAGCCGAGTGATGTACAAGG & TAAACGGGAAATCTGCACCT \\
\hline Creatine kinase, muscle & NM_007710 & CAGCACAGACAGACACTCAGG & GAACTTGTTGTGGGTGTTGC \\
\hline Voltage-dependent anion channel 1 & NM_011694 & ACCTTTGATTCGTCATTCTCG & TGCTCCCTCTTGTACCCTGT \\
\hline Lactate dehydrogenase A-4 & M17518 & CTGCCAACTGTATGCAGTCTTT & ATGTTTGGTGAGGGTGTGC \\
\hline
\end{tabular}

To confirm the differential expression of genes of perfused mouse hearts revealed by microarray analysis we selected 17 genes for QRT-PCR analysis. 
Table 2

Comparison of gene expression changes observed by microarray and quantitative real-time RT-PCR

\begin{tabular}{|c|c|c|c|c|c|c|c|}
\hline Gene product & $\begin{array}{l}\text { Accession } \\
\text { number }\end{array}$ & $\begin{array}{l}\text { Ratio (SD) } \\
\text { chip } 60^{\prime}\end{array}$ & $\begin{array}{l}\text { Ratio (SD) } \\
\text { QRT-PCR 60' }\end{array}$ & $\begin{array}{l}\text { Confirmed by } \\
\text { QRT-PCR }\end{array}$ & $\begin{array}{l}\text { Ratio (SD) } \\
\text { chip } 120^{\prime}\end{array}$ & $\begin{array}{l}\text { Ratio (SD) } \\
\text { QRT-PCR } 120^{\prime}\end{array}$ & $\begin{array}{l}\text { Confirmed by } \\
\text { QRT-PCR }\end{array}$ \\
\hline$N$-deacetylase/ $N$-sulfotransferase 2 & NM_010811 & $-1.27(0.54)$ & $-1.69(0.20)$ & Yes & $-1.11(0.43)$ & $-1.25(0.35)$ & Yes \\
\hline $\begin{array}{l}\text { Beta-1,4- } N \text {-acetyl-galactosaminyl } \\
\text { transferase } 1\end{array}$ & NM_008080 & $-1.52(0.37)$ & $-1.8(0.14)$ & Yes & $-1.06(0.26)$ & $-2.17(0.20)$ & Yes \\
\hline G two $\mathrm{S}$ phase expressed protein 1 & NM_013882 & $-1.25(0.33)$ & $-1.44(0.29)$ & Yes & $+0.36(0.33)$ & $-1.80(0.19)$ & No \\
\hline $\begin{array}{l}\text { Microtubule-associated protein, } \mathrm{RP} / \mathrm{EB} \\
\text { family, member } 1\end{array}$ & NM_007896 & $-1.24(2.16)$ & $-2.01(0.25)$ & Yes & $-2.11(1.32)$ & $-1.87(0.37)$ & Yes \\
\hline Ketohexokinase & NM_008439 & $-1.24(0.77)$ & $-2.28(0.84)$ & Yes & $-0.56(0.87)$ & $-2.03(0.50)$ & Yes \\
\hline Integral membrane protein $2 \mathrm{~B}$ & NM_008410 & $-1.24(1.24)$ & $-2.02(0.55)$ & Yes & $-0.70(1.40)$ & $-1.25(0.23)$ & Yes \\
\hline Casein kinase II, alpha 2 , polypeptide & NM_009974 & $+1.08(0.29)$ & $-2.84(0.36)$ & No & $+0.14(0.31)$ & $-3.38(0.32)$ & No \\
\hline $\begin{array}{l}\text { Disintegrin and metalloprotease } \\
\text { domain } 3 \text { (cyritestin) }\end{array}$ & NM_009619 & $+1.19(0.65)$ & $-0.83(0.09)$ & No & $+1.37(0.41)$ & $-1.03(0.17)$ & No \\
\hline Troponin T1, skeletal, slow & NM_011618 & $-1.08(0.75)$ & $-1.30(0.43)$ & Yes & $-1.60(0.54)$ & $-2.44(0.48)$ & Yes \\
\hline $\begin{array}{l}\text { Acetyl-Coenzyme A dehydrogenase, } \\
\text { long-chain }\end{array}$ & NM_007381 & $-0.72(0.70)$ & $-3.25(1.52)$ & Yes & $-1.54(0.62)$ & $-4.03(1.73)$ & Yes \\
\hline Integrin alpha 7 & NM_008398 & $-0.26(0.87)$ & $+4.06(1.37)$ & No & $-1.33(0.97)$ & $-2.82(1.24)$ & Yes \\
\hline Chloride ion current inducer protein & U53455 & $-1.39(1.32)$ & $-5.42(0.83)$ & Yes & $-1.27(2.20)$ & $-6.04(1.21)$ & Yes \\
\hline $\begin{array}{l}\text { Protein phosphatase } 1 \text {, regulatory } \\
\quad \text { (inhibitor) subunit } 14 \mathrm{~B}\end{array}$ & NM_008889 & $-0.12(0.41)$ & $-0.51(0.23)$ & No & $-1.06(1.14)$ & $-1.32(0.24)$ & Yes \\
\hline Interleukin 12 receptor, beta 1 & NM_008353 & $-3.20(3.48)$ & $-1.26(0.32)$ & Yes & $-0.72(1.46)$ & $-1.57(0.29)$ & Yes \\
\hline Creatine kinase, muscle & NM_007710 & $-1.51(0.61)$ & $-1.47(0.24)$ & Yes & $-1.15(0.54)$ & $-1.95(0.02)$ & Yes \\
\hline Voltage-dependent anion channel 1 & NM_011694 & $-1.43(0.38)$ & -2.61 (n.d.) & Yes & $-2.66(0.50)$ & -2.01 (n.d.) & Yes \\
\hline Lactate dehydrogenase A-4 & M17518 & $-0.63(0.32)$ & -0.81 (n.d.) & Yes & $-0.92(0.75)$ & -1.28 (n.d.) & Yes \\
\hline
\end{tabular}

Relative gene expression changes in mouse hearts in response to 60 and 120 min perfusion were compared to the expression profile of the control animals by microarray and quantitative real-time polymerase chain reaction (QRT-PCR) analysis. Two genes exhibited significant up-regulation and 15 were down-regulated.

Decreased transcription activity of gene for Chloride ion current inducer protein was detected after 60 and $120 \mathrm{~min}$ of normoxic perfusion.

Genes, encoding two apoptotic proteins presented significant repression in response to perfusion: Integral membrane protein 2B and Voltage-dependent anion channel 1 (Vdac1). As the microarray and the QRT-PCR results evidenced, repression is more pronounced over the increase of perfusion time.

Perfusion repressed several genes including some signal transduction genes. One of them, the integrin alpha 7 didn't show altered expression after $60 \mathrm{~min}$ of perfusion, but after $120 \mathrm{~min}$, it was strongly repressed. The interleukin 12 receptor beta-1 subunit gene was also strongly attenuated at the mRNA level in comparison to the control group even after $60 \mathrm{~min}$ perfusion.

A disintegrin and metalloprotease domain 3 (adam 3 ) had a very significant rise in transcription rate. Protein phosphatase 1 regulatory subunit $14 \mathrm{~B}$ became repressed only after $120 \mathrm{~min}$ of perfusion.

Two genes have shown altered expression among the muscle contraction regulators. Our results show that 60 and 120 min of perfusion also induced repression of Creatine kinase muscle (Ckmm). The repression rate of Troponin T1, skeletal (Tnnt1) grows with the increase of perfusion time.

\subsection{Expression profiling of genes related to ischemic adaptation}

Measurement of expression at mRNA level of an additional 19 genes strongly related to cardiac adaptation to ischemiareperfusion but not available on the microarrays was also investigated by QRT-PCR (Table 3).
Superoxide dismutase (SOD) enzyme catalyzes the reduction of superoxide anions to hydrogen peroxide, as such, it is an important antioxidant. Three superoxide dismutases are characterized by different metal content. According to our results
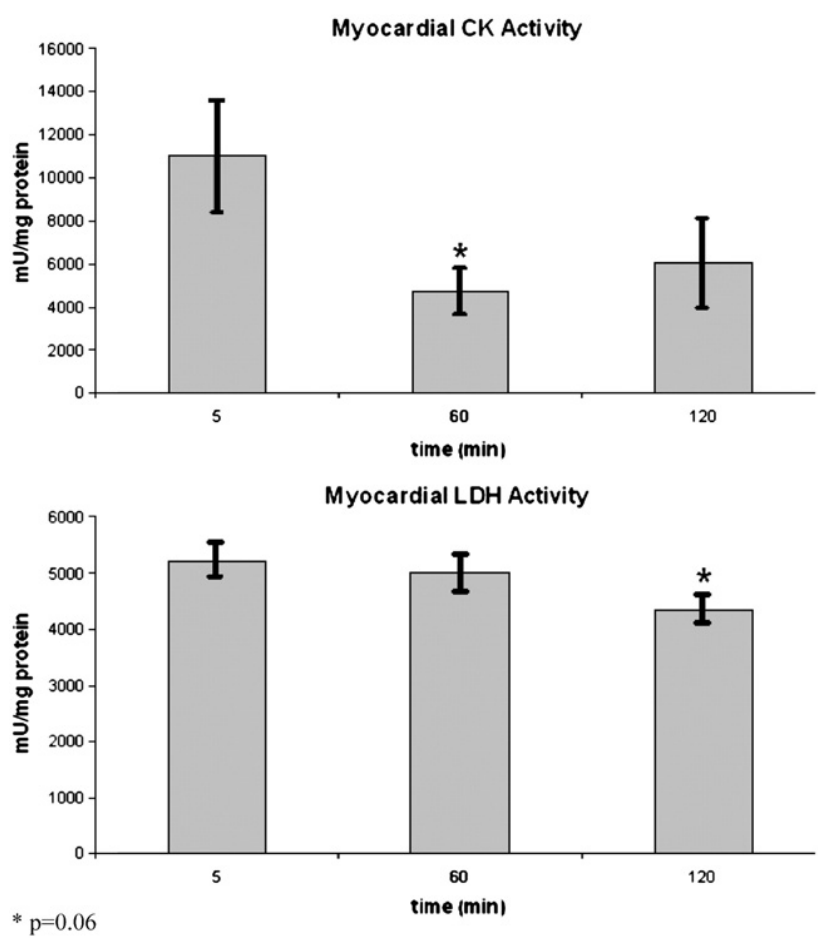

Fig. 1. CK and LDH enzymatic activity measurements. According to the microarray and QRT-PCR analysis, creatine kinase (ck) and lactate dehydrogenase (ldh) genes are being repressed after 60 and 120 min of perfusion. CK and $\mathrm{LDH}$ enzymatic activities in the heart extracts were determined to detect decline in gene expression of genes coding for these enzymes. $* p=0.06$. 
Table 3

Measurement of expression ratio at mRNA level by QRT-PCR

\begin{tabular}{|c|c|c|c|c|c|}
\hline Gene product & $\begin{array}{l}\text { Accession } \\
\text { number }\end{array}$ & Forward primer & Reverse primer & $\begin{array}{l}\text { Ratio (SD) } \\
60^{\prime}\end{array}$ & $\begin{array}{l}\text { Ratio (SD) } \\
120^{\prime}\end{array}$ \\
\hline Superoxide dismutase-1 & NM_011434 & TTTTTTTGCGCGGTCCTTT & ACCAGAGAGAGCAAGACGAGAAG & $1.00(0.79)$ & $1.07(0.93)$ \\
\hline Superoxide dismutase- 2 & NM_013671 & TTAACGCGCAGATCATGCA & GGTGGCGTTGAGATTGTTCA & $1.05(1.77)$ & $1.15(0.81)$ \\
\hline Superoxide dismutase- 3 & NM_011435 & CATGCAATCTGCAGGGTACAA & CGGTGATCTGCGGCTGAT & $0.84(1.42)$ & $1.27(1.17)$ \\
\hline NADPH oxidase-1 & NM_172203 & CCCAGCAGAAGGTCGTGATT & CCTCATCTGCAATTCCAAAACA & $1.87(1.13)$ & $3.15(1.68)$ \\
\hline NADPH oxidase-4 & BC021378 & GATTTCTGGACCTTTGTGCCTTT & TGATGGTGACAGGTTTGTTGCT & $0.84(0.26)$ & $0.31(0.27)$ \\
\hline Nitric oxide synthase 1 & NM_008712 & CACCCACCAAAGCTGTCGAT & CTGCTAATGGCTGGTCTTTGC & $1.04(0.65)$ & $0.66(4.17)$ \\
\hline Nitric oxide synthase 2 & NM_010927 & GGCAGCCTGTGAGACCTTTG & CATTGGAAGTGAAGCGTTTCG & $0.25(0.57)$ & $0.18(0.28)$ \\
\hline Matrix metalloproteinase-2 & NM_008610 & CCCATGAAGCCTTGTTTACCA & TGGAAGCGGAACGGAAACT & $1.20(0.24)$ & $1.61(0.32)$ \\
\hline $\begin{array}{l}\text { Tissue inhibitor of } \\
\text { metalloproteinase } 1\end{array}$ & NM_011593 & GCAAAGAGCTTTCTCAAAGACC & AAGGGATAGATAAACAGGGAAACA & $1.75(0.55)$ & $1.86(0.88)$ \\
\hline $\begin{array}{l}\text { Tissue inhibitor of } \\
\text { metalloproteinase } 2\end{array}$ & NM_011594 & CGTTTTGCAATGCAGACGTA & GGAATCCACCTCCTTCTCG & $0.70(0.35)$ & $0.52(0.10)$ \\
\hline $\begin{array}{l}\text { Tissue inhibitor of } \\
\text { metalloproteinase } 3\end{array}$ & $\mathrm{BC} 014713$ & GCCTCAAGCTAGAAGTCAACAAA & TGTACATCTTGCCTTCATACACG & $0.79(1.12)$ & $1.02(0.78)$ \\
\hline $\begin{array}{l}\text { Tissue inhibitor of } \\
\text { metalloproteinase } 4\end{array}$ & NM_080639 & AGGGAGAGCCTGAATCATCA & GCACTGCATAGCAAGTGGTG & $0.97(1.04)$ & $0.33(0.93)$ \\
\hline HMG-CoA reductase & NM_008255 & TCTGGCAGTCAGTGGGAACTATT & CCTCGTCCTTCGATCCAGTTT & $1.18(0.19)$ & $1.19(0.25)$ \\
\hline $\begin{array}{l}\text { Farnesyl diphosphate farnesyl } \\
\text { transferase } 1\end{array}$ & $\mathrm{BC} 054722$ & TGAACTCATAACCAACACCCTACAG & TGGTTCCGGAGCCTTGAC & $1.07(1.26)$ & $1.07(0.89)$ \\
\hline Heat shock protein $25 \mathrm{kDa} 2$ & AK030025 & AGCTCACAGTGAAGACCAAGG & CATGTTCGTCCTGCCTTTCT & $1.38(1.11)$ & $1.20(0.80)$ \\
\hline NADH dehydrogenase & ВС081434 & GCTTGCTTCGGTACAAAACG & GGGGTGTATTTGCCCTCTTT & $0.37(0.45)$ & $0.89(0.45)$ \\
\hline Geranyl geranyl transferase & BC012214 & TGCTAAATGGCCAGACAGTCAT & TGAGTGACAGGCCGCAGAT & $1.18(0.77)$ & $1.39(1.10)$ \\
\hline Low density lipoprotein & NM_010700 & GATGGCTATACCTACCCCTCAA & TGCTCATGCCACATCGTTC & $1.11(1.02)$ & $1.14(0.72)$ \\
\hline Matrix metalloproteinase-9 & NM_013599 & ACGACATAGACGCCATCCA & GCTGTGGTTCAGTTGTGGTTG & $1.20(0.26)$ & $1.55(0.51)$ \\
\hline
\end{tabular}

The expression of an additional 19 genes strongly related to ischemia-reperfusion but that were not available on the microarrays was also investigated by QRT-PCR (in normoxic perfused mouse hearts related to control).

each types of sod represents over-expression after 60 and $120 \mathrm{~min}$ of perfusion.

The NADPH oxidase is a multi-subunit enzyme that catalyzes the reduction of molecular oxygen to form superoxide. According to our results, the over-expression of NOX enzymes (and in this way the amount of reactive oxygen species) increases directly proportional to perfusion time.

We observed increasing activity in case of two matrix metalloproteinase genes, $m m p 2$ and $m m p 9$. Genes coding for Matrix metalloproteinases 2 and 9 (MMP2 and MMP9) were overexpressed due to perfusion in both groups.

We have also detected increasing expression of low density lipoprotein gene after 60 and $120 \mathrm{~min}$.

Among the four tissue inhibitor of metalloproteinase (timp) genes investigated in our study, only inhibitor of metalloproteinase- 1 showed altered expression. We observed about 1.80 fold over-expression after 60 and 120 min of perfusion.

The Nitric oxide synthases (NOS) are a group of enzymes responsible for the synthesis of nitric oxide (NO) from the terminal nitrogen atom of $\mathrm{L}$-arginine in the presence of $\mathrm{O}_{2}$ and certain cofactors. The nitric oxide molecule is a free radical, that makes it very reactive and unstable and in high concentration it has cytotoxic effects. We have shown that perfusion inhibits expression of cardiac nitric oxide synthases 2 (nos2).

Our results show that 60 and $120 \mathrm{~min}$ of perfusion induced over-expression of gene for $25-\mathrm{kDa}$ Heat shock protein (HSP25).

Geranyl geranyl transferase, HMG-CoA reductase, farnesyl diphosphate farnesyl transferase 1 and NADH dehydrogenase have been studied previously in response to ischemia-reperfusion.
One of them, the NADH dehydrogenase didn't show altered expression after perfusion. At the other three genes we confirmed up-regulation of transcription due to perfusion.

\subsection{Enzymatic activities}

CK and LDH activities in the heart extracts $(n=4$ in each group) were also determined as we could detect decline in gene expression of genes coding for these enzymes. According to the microarray analysis and QRT-PCR results, $c k$ and $l d h$ genes are being repressed after 60 and $120 \mathrm{~min}$ of perfusion and this rate of repression is more pronounced over the increase of perfusion time. The enzyme activity measurements (results are shown in Fig. 1) showed that creatine kinase and lactate dehydrogenase levels were also decreased due to perfusion.

Hemodynamic parameters, like coronary flow and heart rate were also measured. None of these parameters changed in the perfused groups (Table 5) when compared to controls.

\section{Discussion}

\subsection{Gene expression alteration due to perfusion}

Perfusion leads to extensive changes in cardiac expression of genes from various functional clusters (Table 4). As shown in Table 5, heart rate and coronary flow were not changed in the perfused groups.

Our present study is the first demonstration in connection with the effects of different long periods of perfusion time in mouse hearts. The role of most genes found to be regulated by 
Table 4

Functional classification of differentially expressed genes

\begin{tabular}{|c|c|c|}
\hline Functional cluster & Gene product & $\begin{array}{l}\text { Accession } \\
\text { number }\end{array}$ \\
\hline \multirow{7}{*}{$\begin{array}{l}\text { Oxidative and nitrosative } \\
\text { stress }\end{array}$} & Superoxide dismutase-1 & NM_011434 \\
\hline & Superoxide dismutase-2 & NM_013671 \\
\hline & Superoxide dismutase- 3 & NM_011435 \\
\hline & NADPH oxidase-1 & NM_172203 \\
\hline & NADPH oxidase-4 & ВC021378 \\
\hline & Nitric oxide synthase 1 & NM_008712 \\
\hline & Nitric oxide synthase 2 & NM_010927 \\
\hline Heat shock proteins & Heat shock protein $25 \mathrm{kDa} 2$ & AK030025 \\
\hline \multirow[t]{4}{*}{ Energy metabolism } & Creatine kinase, muscle & NM_007710 \\
\hline & NADH dehydrogenase & ВC081434 \\
\hline & Lactate dehydrogenase A-4 & M17518 \\
\hline & $\begin{array}{l}\text { Acetyl-Coenzyme A } \\
\text { dehydrogenase, long-chain }\end{array}$ & NM_007381 \\
\hline \multirow{4}{*}{$\begin{array}{l}\text { Cholesterol synthesis, } \\
\text { transport }\end{array}$} & HMG-CoA reductase & NM_008255 \\
\hline & Low density lipoprotein & NM_010700 \\
\hline & $\begin{array}{l}\text { Farnesyl diphosphate } \\
\text { farnesyl transferase } 1\end{array}$ & BC054722 \\
\hline & Geranyl geranyl transferase & $\mathrm{BC} 012214$ \\
\hline Muscle contraction & Troponin T1, skeletal, slow & NM_011618 \\
\hline \multirow[t]{5}{*}{$\begin{array}{l}\text { Ion channels, receptors, } \\
\text { membrane proteins }\end{array}$} & $\begin{array}{l}\text { Voltage-dependent anion channel } \\
1\end{array}$ & NM_011694 \\
\hline & $\begin{array}{l}\text { Chloride ion current inducer } \\
\text { protein }\end{array}$ & U53455 \\
\hline & Interleukin 12 receptor, beta 1 & NM_008353 \\
\hline & Integral membrane protein $2 \mathrm{~B}$ & NM_008410 \\
\hline & Integrin alpha 7 & NM_008398 \\
\hline \multirow[t]{3}{*}{ Regulation of cell cycle } & $\begin{array}{l}\text { G two } S \text { phase expressed } \\
\text { protein } 1(\text { Gtse } 1)\end{array}$ & NM_013882 \\
\hline & $\begin{array}{l}\text { Microtubule-associated protein, } \\
\text { RP/EB family, member } 1\end{array}$ & NM_007896 \\
\hline & $\begin{array}{l}\text { Casein kinase II, alpha } 2 \text {, } \\
\text { polypeptide }\end{array}$ & NM_009974 \\
\hline \multirow[t]{3}{*}{ Metabolic enzymes } & $\begin{array}{l}N \text {-deacetylase/ } \\
N \text {-sulfotransferase } 2\end{array}$ & NM_010811 \\
\hline & $\begin{array}{l}\text { Beta-1,4- } N \text {-acetyl-galactosaminyl } \\
\text { ransferase } 1 \text { (Galgt1) }\end{array}$ & NM_008080 \\
\hline & Ketohexokinase (KhK) & NM_008439 \\
\hline Protein phosphorylation & $\begin{array}{l}\text { Protein phosphatase } 1 \text {, regulatory } \\
\text { (inhibitor) subunit } 14 \mathrm{~B}\end{array}$ & NM_008889 \\
\hline \multirow{7}{*}{$\begin{array}{l}\text { Proteolysis and } \\
\text { peptidolysis }\end{array}$} & Matrix metalloproteinase-2 & NM_008610 \\
\hline & Matrix metalloproteinase-9 & NM_013599 \\
\hline & $\begin{array}{l}\text { Disintegrin and metalloprotease } \\
\text { domain } 3 \text { (cyritestin) }\end{array}$ & NM_009619 \\
\hline & $\begin{array}{l}\text { Tissue inhibitor of } \\
\text { metalloproteinase } 1\end{array}$ & NM_011593 \\
\hline & $\begin{array}{l}\text { Tissue inhibitor of } \\
\text { metalloproteinase } 2\end{array}$ & NM_011594 \\
\hline & $\begin{array}{l}\text { Tissue inhibitor of } \\
\text { metalloproteinase } 3\end{array}$ & ВC014713 \\
\hline & $\begin{array}{l}\text { Tissue inhibitor of } \\
\text { metalloproteinase } 4\end{array}$ & NM_080639 \\
\hline
\end{tabular}

According to the microarray and quantitative real-time polymerase chain reaction (QRT-PCR) analysis 36 genes showed altered expression after 60 and $120 \mathrm{~min}$ of perfusion of mouse hearts.

perfusion is not exactly known in the heart, therefore, our present findings may open new directions in research of the cardiac effects of perfusion.
Enzymatic activity measurements proved that perfusion decreased significantly the $\mathrm{LDH}$ and $\mathrm{CK}$ activity correlating to the non-perfused control group and that was confirmed by microarray results.

Heparan sulfate (HS) proteoglycans influence embryonic development through interactions with growth factors and morphogens. Interactions depend on HS structure that is largely determined by biosynthesis in Golgi (Holmborn et al., 2004).

Glucosaminyl- $N$-deacetylase $/ N$-sulfotransferase 2 (Ndst2), responsible for HS $N$-sulfation, is the key enzyme directing further modifications including $O$-sulfation. This gene product hasn't been correlated with ischemia or perfusion yet (Carter, Ali, \& Kirby, 2003).

Galgt1 is an important determinant of plasma VWF (von Willebrand factor) levels in mouse (Ginsburg, 2005; Mohlke et al., 1999).

Changes in the expression of other cell cycle regulatory genes showed down-regulation, which were also confirmed by QRT-PCR. Some studies have already demonstrated that the gene, encoding Microtubule-associated protein 1 shows altered expression in response to the developement of ischemia in the rat retina (Mastrodimou, Lambrou, \& Thermos, 2005) and in response to autophagy in chronically ischemic myocardium (Yan et al., 2005). According to our results, the repression of Mtap1 increases directly proportional to time of normoxic perfusion.

Gtse1 (previously named B99) showed down-regulation after only 120 min of perfusion. This is a wt-p53 inducible gene that encodes a microtubule-localized protein which is able to induce $\mathrm{G}(2) / \mathrm{M}$ phase accumulation when ectopically expressed. The function of Gtse1 in the myocardium is presently unknown.

Ketohexokinase 1 catalyses the phosphorylation of fructose to fructose-1-phosphate. Khk expression had a significant decline after 60 and also 120 min of perfusion. This enzyme is expressed predominantly in the liver, to a lesser extent in the kidney, and very little in heart, brain and muscle (Bais, James, Rofe, \& Conyers, 1985).

A key enzyme of the glycolysis, lactate dehydrogenase A-4 is a well-established marker of cardiac damage. Karaca studied the expression alteration of lactate dehydrogenase gene, induced by ischemia-reperfusion. They previously proved that the expression of $l d h$ gene rises in response to ischemia (Karaca et al., 2006; Xu et al., 2006), but at the same time our results have shown that in response to normoxic perfusion LDH was down-

Table 5

Cardiac functional parameters in control and perfused groups

\begin{tabular}{lllllll}
\hline & $\begin{array}{l}5^{\prime} \\
(\text { mean })\end{array}$ & $\begin{array}{l}5^{\prime} \\
(\text { SEM })\end{array}$ & $\begin{array}{l}60^{\prime} \\
(\text { mean })\end{array}$ & $\begin{array}{l}60^{\prime} \\
(\text { SEM })\end{array}$ & $\begin{array}{l}120^{\prime} \\
(\text { mean })\end{array}$ & $\begin{array}{l}120^{\prime} \\
(\text { SEM })\end{array}$ \\
\hline $\begin{array}{c}\text { Heart rate } \\
\quad \text { (beats/min) }\end{array}$ & 437 & 23 & 443 & 20 & 424 & 11 \\
$\begin{array}{c}\text { Coronary flow } \\
(\mathrm{ml} / \text { min) }\end{array}$ & 3.3 & 0.3 & 3.3 & 0.2 & 3.2 & 0.2 \\
$\begin{array}{c}\text { Heart weight } \\
(\mathrm{mg})\end{array}$ & 163 & 6 & 163.5 & 6 & 149.8 & 9 \\
\hline
\end{tabular}

Hemodynamic parameters, like coronary flow and heart rate were also measured. None of these parameters changed in the perfused groups when compared to controls. 
regulated in the mouse heart. Acyl-CoA dehydrogenases (ACADs) are a family of mitochondrial enzymes catalyzing the initial rate-limiting step in the beta-oxidation of fatty acylCoA (Thorpe \& Kim, 1995). This reaction provides the main source of energy for human heart and skeletal muscle. Deficiency of the long-chain Acyl-CoA dehydrogenase (LCAD), usually leads to human organic diseases, such as sudden death in infancy, cardiomyopathy and hypoketotic hypoglycemia (Zhang et al., 2002). In our study we have detected a significant fall in LCAD transcription rate, but only after $2 \mathrm{~h}$ of perfusion.

Decreased mRNA levels of chloride ion current inducer were detected after 60 and $120 \mathrm{~min}$ of normoxic perfusion. This gene has already been studied in rat brain and myocardium, but the gene function only described in ocular ciliary epithelium (Anguita, Chalfant, Civan, Coca-Prados , 1995; Wan, Chen, \& Sears, 1997).

Genes, coding for two apoptotic proteins presented significant repression in response to perfusion. One of them, the gene, encoding Integral membrane protein $2 \mathrm{~B}$ is supposedly connected with the development of dementia (Wolfe et al., 1999). The other apoptotic gene, voltage-dependent anion channell (Vdac1) exhibited one of the most pronounced repressions due to perfusion. Previously Anflous, Armstrong, and Craigen (2001) proved that Vdac1 was required for creatine stimulation of mitochondrial respiration in oxidative muscles. As the microarray and the QRT-PCR results evidenced, repression rate of $\mathrm{Vdac} 1$ increases directly proportional to the increase in perfusion time.

Perfusion repressed several genes including some signal transduction genes. One of them, the integrin alpha 7 didn't show altered expression after $60 \mathrm{~min}$ of perfusion, but after $120 \mathrm{~min}$ it was strongly repressed. Integrin alpha 7 is a specific cellular receptor for the basement membrane protein Laminin-1, as well as for the Laminin isoforms 2 and 4. The alpha 7 subunit is expressed mainly in skeletal and cardiac muscle and has been suggested to be involved in differentiation and migration processes during myogenesis. Mayer et al. (1997) studied the involvement of Integrin alpha 7, during myogenesis and its role in muscle integrity and function. They proved that absence of this protein causes muscular dystrophy.

The interleukin 12 receptor beta-1 gene also represents strongly attenuated function correlated to the control in both groups. Myocardial function of that is not known yet, but recently Kutukculer et al. (2006) associated the interleukin-12 receptor beta-1 deficiency with cutaneous leukocytoclastic vasculitis.

The gene coding A disintegrin and metalloprotease domain 3 (Adam3) had a very significant rise in transcription rate. This gene may play a role in cell-cell and cell-matrix interactions during spermatogenesis. The myocardial role of Adam3 is not known so far, but Adam10, Adam15 and Adam19 from the same gene family demonstrably show altered expression during cardiomyopathy (Fedak, Moravec, \& McCarthy, 2006; Kurohara, Komatsu, Kurisaki, \& Masuda, 2004).

Protein phosphatase 1 regulatory subunit 14B became repressed only after 120 min of perfusion. Ppp1r14b provides a regulator function by controlling protein phosphatases.
Two genes have shown altered expression among the muscle contraction regulators. Our results showed that 60 and $120 \mathrm{~min}$ of perfusion also induce repression of creatine kinase muscle (ckmm). Ckmm is expressed by various tissue types. Its function is the catalysis of the conversion of creatine to phosphocreatine, consuming ATP and generating ADP. Andres, Sharma, and Sassen (1993) realised that this key enzyme of intracellular energy transduction is altered in porcine myocardium subjected to repeated brief periods of ischemia, but they haven't noticed any changes in $\mathrm{ckmm}$ gene expression during perfusion.

The repression rate of troponin $T 1$ skeletal (tnnt1) rose with the increase of perfusion time in our present study. Tnntl can be found principally in skeletal muscle. Troponin $T 2$ with similar structure and functions has previously represented altered expression in response to ischemia-reperfusion and it is suitable to detect myocardial injuries (Sobki, Saadeddin, \& Habbab, 2000).

\subsection{Expression profiling of genes related to ischemic adaptation}

Expression rate at mRNA level of an additional 19 genes (Table 3) strongly related to cardiac adaptation to ischemiareperfusion but not available on the microarrays was also investigated by QRT-PCR (Table 3).

During reperfusion, when blood supply returns to the tissue after a period of ischemia, the absence of oxygen and nutrients from blood creates a condition in which the restoration of circulation results in inflammation and oxidative damage from the oxygen rather than restoration of normal function. This oxidation results that molecular oxygen being converted into highly reactive superoxide and hydroxyl radicals. The aim of our study was to identify those genes that changed only due to perfusion.

Superoxide dismutase (SOD) catalyzes the reduction of superoxide anions to hydrogen peroxide and, as such, it is an important antioxidant. SOD is an intracellular enzyme present essentially in every cell of the body. Three SOD isoenzymes are known characterized by different metal content (Ferdinandy \& Schulz, 2003). According to our results each type of SOD shows over-expression after 60 and $120 \mathrm{~min}$ of perfusion. Yoshida, Maulik, Engelman, and Ho (2000) previously proved that SOD I (-/-) mouse hearts are more susceptible to ischemic reperfusion injury compared with corresponding wild-type mouse hearts, suggesting that the sodl gene constitutes an important defense element for the hearts.

NADPH oxidase is a multi-subunit enzyme that catalyzes the reduction of molecular oxygen to superoxide. Superoxide (and associated reactive oxygen species, ROS) generated by NADPH oxidase in non-phagocytic cells serves several functions in health and disease (Cave et al., 2006). A major concept in redox signaling is that while NADPH oxidase-derived ROSs are necessary for normal cellular function, excessive oxidative stress can contribute to pathological disease (Infanger, Sharma, \& Davisson, 2006). According to our results, the overexpression of NOX enzymes (and by this way the amount of reactive oxygen species) increase directly proportional to perfusion time. 
Matrix metalloproteinases (MMPs) are Zn-dependent endopeptidases. Collectively they are capable of degrading many extracellular matrix proteins, but also can process a number of bioactive molecules (Chow, Cena, \& Schulz, 2007). They are known to be involved in the cleavage of cell surface receptors, release of apoptotic ligands and chemokine activation. MMPs are also thought to play a major role on other cell behaviors such as cell proliferation, migration, differentiation, angiogenesis, apoptosis and host defense. We observed increased mRNS levels in case of two matrix metalloproteinase genes; $m m p 2$ and mmp9. Matrix metalloproteinases 2 and 9 (MMP-2 and MMP-9) are increased in the rat brain after experimental ischemic stroke and they also contribute to myocardial remodeling after myocardial infarction (Machado et al., 2006; Mori, Gibson, \& McTiernan, 2006) as well as in the development of acute infarction (Giricz et al., 2006). In our study these genes exhibited almost the most pronounced over-expressions due to perfusion.

We also detected increasing gene expression at the gene for low density lipoprotein. LDL cholesterol is the so called "bad" cholesterol, which carries mostly fat and only a small amount of protein from the liver to other cell types of the body. A high LDL cholesterol level is considered a risk factor for coronary artery disease because, under certain conditions, it leads to atherosclerosis and interferes with cardioprotective mechanisms (Ferdinandy, Schulz, \& Baxter, 2007). Oxidative modification of lipoproteins appears to play an important role in the atherogenic process. oxLDL is involved in inducing smooth muscle cell migration and proliferation, and are avidly ingested by macrophages, resulting in foam cell formation (Mertens \& Holvoet, 2002). Our results suggest that the expression of LDL rises during perfusion and due to the perfusion-formed radicals LDL changes into its oxidating form (oxLDL). Geranyl geranyl transferase, hmg-CoA reductase, farnesyl diphosphate farnesyl transferase 1 genes involved in cholesterol biosynthesis exhibited up-regulation due to perfusion.

Tissue inhibitor of metalloproteinase (TIMP) enzymes play an important role in histogenesis and organogenesis (Werb \& Chin, 1998). Matrix metalloproteinases are proteolytic enzymes which degrade extracellular matrix and basement membrane. Tissue inhibitor of metalloproteinases are the specific inhibitors of MMPs. Circulating levels of MMPs and TIMPs could reflect the atherosclerotic process occurring within the arterial wall and have been identified in normal and failing myocardium (Spinale, 2002). Recent studies suggest that MMPs and TIMPs play a role in various cardiovascular diseases including atherosclerosis and ventricular remodeling observed in heart failure (Mori et al., 2006).

The nitric oxide synthases (NOS) are a group of enzymes responsible for the synthesis of nitric oxide (NO) from the terminal nitrogen atom of L-arginine in the presence of $\mathrm{O}_{2}$ and further cofactors. Nitric oxide plays role in many physiological function and pathological states of the heart (Ferdinandy \& Schulz, 2003). We have shown that perfusion inhibits expression of cardiac nos 2, but activates the expression of nos 1 .

Heat shock proteins are interesting new target for cardioprotection (Söti et al., 2005) The $25-\mathrm{kDa}$ heat-shock protein
(Hsp25) is expressed in the cartilage of the growth plate and suggested to function in chondrocyte differentiation and degeneration. It has demonstrably have cardioprotective effect, but the detailed mechanism is not known yet (Chiu \& Ko, 2004). Our present results show that 60 and $120 \mathrm{~min}$ of perfusion induce over-expression of $h s p 25$.

\section{Limitations of the study}

The stability of the preparation upon long-term perfusion is a general concern in isolated heart preparations. Here we used a Langendorff preparation with no left ventricular balloon to unload the heart from 'afterload pressure' and to maintain a good coronary perfusion throughout the perfusion protocol. As shown in Table 5, heart rate and coronary flow were stable which show the stable aerobic condition of the heart. As the present study was performed in crystalloid-perfused isolated mouse hearts and the analysis of gene expression was done using cardiac tissue that did not contain components of blood, cellular regulatory pathways might be somewhat different in the present ex vivo experimental model as compared to in vivo situations. Perfusion with blood might solve this issue, however, blood perfusion can be a problem in itself (Clements-Jewery et al., 2002). In our present studies, to avoid spontaneous occurrence of arrhythmias, we used a perfusion buffer containing high potassium. Since the gene expression pattern in mice hearts were measured first at $60 \mathrm{~min}$, the results might not be relevant for e.g. studies on ischemiainduced arrhythmias which need shorter perfusion time (Curtis, 1998). It is of interest, however, that in isolated hearts, phase 2 ischaemic arrhythmias are not observed (Ravingerová, Tribulová, Slevák, \& Curtis, 1995). This could be due to the extensive changes in gene expression observed in the present study. It should be noted that the gene expression changes observed here may be specific for isolated mice heart perfusion and the results have less relevance in heart perfusion preparations in other species.

\section{Conclusions}

Our results show that normoxic crystalloid perfusion itself results in time-dependent changes in cardiac gene expression. As many of these genes with altered expression have been suspected to influence several cardiovascular pathologies, this should be considered when designing ex vivo perfusion protocols in the mouse heart to study cardiac diseases.

\section{Acknowledgements}

The investigation conforms to the Guide for the Care and Use of Laboratory Animals published by the US National Institutes of Health (NIH publication No. 85-23, revised 1996) and was approved by specific national laws (e. g. the current version of the German Law on the Protection of Animals) and local ethics committees.

This work was supported by grants from the Hungarian Ministry of Health (ETT 597/2006, ETT 515/2003), the Hungarian Scientific 
Research Fund (OTKA F 046810, T046417, F049574), and the National Office for Research and Technology (RET OMFB-00067/ 2005, Asboth-2005, Jedlik NKFP-A1-2006-0029, NKFP-07-1ES2HEART). T.C. is holding a János Bolyai fellowship.

\section{References}

Andres, J., Sharma, H. S., \& Sassen, L. M. (1993). Reperfusion after brief repetitive ischemia in porcine myocardium does not alter expression of creatine kinase MM or mitochondrial ATPase mRNAs. Journal of Physiology and Pharmacology, 44, 333-344.

Anflous, K., Armstrong, D. D., \& Craigen, W. J. (2001). Altered mitochondrial sensitivity for ADP and maintenance of creatine-stimulated respiration in oxidative striated muscles from VDAC1-deficient mice. Journal of Biological Chemistry, 276, 1954-1960

Anguita, J., Chalfant, M. L., Civan, M. M., \& Coca-Prados, M. (1995). Molecular cloning of the human volume-sensitive chloride conductance regulatory protein, $\mathrm{pICln}$, from ocular ciliary epithelium. Biochemical and Biophysical Research Communication, 208, 89-95

Bais, R., James, H. M., Rofe, A. M., \& Conyers, R. A. (1985). The purification and properties of human liver ketohexokinase. A role for ketohexokinase and fructose-bisphosphate aldolase in the metabolic production of oxalate from xylitol. Biochemical Journal, 230, 53-60.

Carter, N. M., Ali, S., \& Kirby, J. A. (2003). Endothelial inflammation: the role of differential expression of $N$-deacetylase $/ N$-sulphotransferase enzymes in alteration of the immunological properties of heparan sulphate. Journal of Cell Science, 116, 3591-3600.

Cave, A. C., Brewer, A. C., Narayanapanicker, A., Ray, R., Grieve, D. J., Walker, S., et al. (2006). NADPH oxidases in cardiovascular health and disease. Antioxidants and Redox Signalling, 8, 691-728.

Chiu, P. Y., \& Ko, K. M. (2004). Schisandrin B protects myocardial ischemiareperfusion injury partly by inducing $\mathrm{Hsp} 25$ and Hsp70 expression in rats. Mollecular and Cellular Biochemistry, 266, 139-144.

Chow, A. K., Cena, J., \& Schulz, R. (2007). Acute actions and novel targets of matrix metalloproteinases in the heart and vasculature. British Journal of Pharmacology, 152, 189-205.

Clements-Jewery, H., Hearse, D. J., \& Curtis, M. J. (2002). The isolated bloodperfused rat heart: an inappropriate model for the study of ischaemia- and infarction-related ventricular fibrillation. British Journal of Pharmacology, 1089-1099.

Csont, T., Viappiani, S., Sawicka, J., Slee, S., Altarejos, J. Y., Batinic-Haberle, I., et al. (2005). The involvement of superoxide and iNOS-derived NO in cardiac dysfunction induced by pro-inflammatory cytokines. Journal of Molecular and Cellular Cardiology, 39, 833-840.

Curtis, M. J. (1998). Characterisation, utilisation and clinical relevance of isolated perfused heart models of ischaemia-induced ventricular fibrillation. Cardiovascular Research, 39, 194-215.

Fedak, P. W., Moravec, C. S., \& McCarthy, P. M. (2006). Altered expression of disintegrin metalloproteinases and their inhibitor in human dilated cardiomyopathy. Circulation, 113, 238-245.

Ferdinandy, P., Panas, D., \& Schulz, R. (1999). Peroxynitrite contributes to spontaneous loss of cardiac efficiency in isolated working rat hearts. American Journal of Physiology, 276, H1861-H1867.

Ferdinandy, P., \& Schulz, R. (2003). Nitric oxide, superoxide, and peroxynitrite in myocardial ischaemia-reperfusion injury and preconditioning. British Journal of Pharmacology, 138, 532-543

Ferdinandy, P., Schulz, R., \& Baxter, G. F. (2007). Interaction of cardiovascular risk factors with myocardial ischemia/reperfusion injury, preconditioning, and postconditioning. Pharmacological Reviews, 59, 418-458.

Gao, C. Q., Sawicki, G., Suarez-Pinzon, W. L., Csont, T., Wozniak, M., Ferdinandy, P., et al. (2003). Matrix metalloproteinase-2 mediates cytokine-induced myocardial contractile dysfunction. Cardiovascular Research, 57, 426-433.

Ginsburg, D. (2005). Identifying novel genetic determinants of hemostatic balance. Journal of Thrombosis and Haemostasis, 3, 1561-1568.

Giricz, Z., Csonka, C., Onody, A., Csont, T., \& Ferdinandy, P. (2003). Role of cholesterol-enriched diet and the mevalonate pathway in cardiac nitric oxide synthesis. Basic Research in Cardiology, 98, 304-310.
Giricz, Z., Lalu, M. M., Csonka, C., Bencsik, P., Schulz, R., \& Ferdinandy, P. (2006). Hyperlipidemia attenuates the infarct size-limiting effect of ischemic preconditioning: role of matrix metalloproteinase-2 inhibition. Journal of Pharmacology and Experimental Therapeutic, 316, 154-161.

Hearse, D. J., Richard, V., Yellon, D. M., \& Kingma, J. G., Jr (1988). Evolving myocardial infarction in the rat in vivo: an inappropriate model for the investigation of drug-induced infarct size limitation during sustained regional ischaemia. Journal of Cardiovascular Pharmacology, 11, 701-710.

Holmborn, K., Ledin, J., Smeds, E., Eriksson, I., Kusche-Gullberg, M., \& Kjellén, L. (2004). Heparan sulfate synthesized by mouse embryonic stem cells deficient in NDST1 and NDST2 is 6-O-sulfated but contains no $N$-sulfate groups. Journal of Biological Chemistry, 279, 42355-42358.

Infanger, D. W., Sharma, R. V., \& Davisson, R. L. (2006). NADPH oxidases of the brain: distribution, regulation, and function. Antioxidant and Redox Signalling, 8, 1583-1596.

Karaca, P., Konuralp, C., Enc, Y., Suzer, A., Sokullu, O., Ayoglu, U., et al. (2006). Cardioprotective effect of aprotinin on myocardial ischemia/ reperfusion injury during cardiopulmonary bypass. Circulation Journal, 70, 1432-1436.

Kurohara, K., Komatsu, K., Kurisaki, T., \& Masuda (2004). Essential roles of Meltrin beta (ADAM19) in heart development. Developments in Biologicals, 267, 14-28.

Kutukculer, N., Genel, F., Aksu, G., Karapinar, B., Ozturk, C., Cavusoglu, C., et al. (2006). Cutaneous leukocytoclastic vasculitis in a child with interleukin-12 receptor beta-1 deficiency. Journal of Pediatrics, 148, 407-409.

Machado, L. S., Kozak, A., Ergul, A., Hess, D. C., Borlongan, C. V., \& Fagan, S. C. (2006). Delayed minocycline inhibits ischemia-activated matrix metalloproteinases 2 and 9 after experimental stroke. BMC Neuroscience, 7, 56.

Mastrodimou, N., Lambrou, G. N., \& Thermos, K. (2005). Effect of somatostatin analogues on chemically induced ischaemia in the rat retina. Naunyn Schmiedeberg's Archives of Pharmacology, 371, 44-53.

Mayer, U., Saher, G., Fassler, R., Bornemann, A., Echtermeyer, F., von der Mark, H., et al. (1997). Absence of integrin alpha 7 causes a novel form of muscular dystrophy. Nature Genetics, 17, 318-323.

Mertens, A., \& Holvoet, P. (2002). Oxidized LDL and HDL: antagonists in atherothrombosis. FASEB Journal, 15, 2073-2084.

Miyashita, T., Kubota, I., Yamaki, M., Watanabe, T., Yamauchi, S., \& Tomoike, H. (2000). 4-aminopyridine inhibits the occurrence of ventricular fibrillation but not ventricular tachycardia in the reperfused, isolated rat heart. Japanese Circulation Journal, 64, 602-605.

Mohlke, K. L., Purkayastha, A. A., Westrick, R. J., Smith, P. L., Petryniak, B., Lowe, J. B., et al. (1999). Mvwf, a dominant modifier of murine von Willebrand factor, results from altered lineage-specific expression of a glycosyltransferase. Cell, 96, 111-120.

Mori, S., Gibson, G., \& McTiernan, C. F. (2006). Differential expression of MMPs and TIMPs in moderate and severe heart failure in a transgenic model. Journal of Cardiac Failure, 12, 314-325.

Onody, A., Zvara, A., Hackler, L., Jr, Vigh, L., Ferdinandy, P., \& Puskas, L. G. (2003). Effect of classic preconditioning on the gene expression pattern of rat hearts: a DNA microarray study. FEBS Letters, 536, 35-40.

Palotas, A., Puskas, L. G., Kitajka, K., Palotas, M., Molnar, J., Pakaski, M., et al. (2004). The effect of citalopram on gene expression profile of Alzheimer lymphocytes. Neurochemical Research, 29, 1563-1570.

Puskás, L. G., Nagy, Z. B., Giricz, Z., Onody, A., Csonka, C., Kitajka, K., et al. (2004). Cholesterol diet-induced hyperlipidemia influences gene expression pattern of rat hearts: a DNA microarray study. FEBS Letters, 562, 99-104.

Puskás, L. G., Zvara, A., Hackler, L., Jr, Micsik, T., \& van Hummelen, P. (2002). Production of bulk amounts of universal RNA for DNA microarrays.Biotechniques, 33, 898-900 (902, 904).

Ravingerova, T., Pancza, D., Ziegelhoffer, A., \& Styk, J. (2005). Preconditioning modulates susceptibility to ischemia-induced arrhythmias in the rat heart: the role of alpha-adrenergic stimulation and K(ATP) channels. Physiological Research, 51, 109-119.

Ravingerová, T., Tribulová, N., Slezák, J., \& Curtis, M. J. (1995). Brief, intermediate and prolonged ischemia in the isolated crystalloid perfused rat heart: relationship between susceptibility to arrhythmias and degree of ultrastructural injury. Journal of Molecular and Cellular Cardiological, 27, 1937-1951. 
Schomisch, S. J., Murdock, D. G., Hedayati, N., Carino, J. L., Lesnefsky, E. J., \& Cmolik, B. L. (2005). Cardioplegia prevents ischemia-induced transcriptional alterations of cytoprotective genes in rat hearts: a DNA microarray study. Journal of Thoracic and Cardiovascular Surgery, 130, 1151.

Sobki, S. H., Saadeddin, S. M., \& Habbab, M. A. (2000). Cardiac markers used in the detection of myocardial injury. Saudi Medical Journal, 21, 843-846.

Sőti, C., Nagy, E., Giricz, Z., Vígh, L., Csermely, P., \& Ferdinandy, P. (2005). Heat shock proteins as emerging therapeutic targets. British Journal of Pharmacology, 146, 769-780.

Spinale, F. G. (2002). Matrix metalloproteinases: regulation and dysregulation in the failing heart. Circulation Research, 90, 520-530.

Sutherland, F. J., \& Hearse, D. J. (2000). The isolated blood and perfusion fluid perfused heart. Pharmacological Research, 41, 613-627.

Thorpe, C., \& Kim, J. J. (1995). Structure and mechanism of action of the acylCoA dehydrogenases. FASEB Journal, 9, 718-725.

Wan, X. L., Chen, S., \& Sears, M. (1997). Cloning and functional expression of a swelling-induced chloride conductance regulatory protein, $\mathrm{plCln}$, from rabbit ocular ciliary epithelium. Biochemistry and Biophysics Research Communication, 239, 692-696.

Werb, Z., \& Chin, J. R. (1998). Extracellular matrix remodeling during morphogenesis. Annals of the New York Academy of Sciences, 857, 110-118.
Wolfe, M. S., De Los Angeles, J., Miller, D. D., Xia, W., \& Selkoe, D. J. (1999). Are presenilins intramembrane-cleaving proteases? Implications for the molecular mechanism of Alzheimer's disease. Biochemistry, 38, 11223-11230.

Xu, D., Li, Y., Wang, J., Davey, A. K., Zhang, S., \& Evans, A. M. (2006). The cardioprotective effect of isosteviol on rats with heart ischemia-reperfusion injury. Life Sciences, 80, 269-274.

Yan, L., Vatner, D. E., Kim, S. J., Ge, H., Masurekar, M., Massover, W. H., et al (2005). Autophagy in chronically ischemic myocardium. Proceedings of the National Academy of Sciences of the United States of America, 102, 13807-13812.

Yang, Y. H., Dudoit, S., Luu, P., Lin, D. M., Peng, V., Ngai, J., et al. (2002) Normalization for cDNA microarray data: a robust composite method addressing single and multiple slide systematic variation. Nucleic Acids Research, 30, e15.

Yoshida, T., Maulik, N., Engelman, R. M., \& Ho, Y. S. (2000). Targeted disruption of the mouse Sod I gene makes the hearts vulnerable to ischemic reperfusion injury. Circulation Research, 86, 264-269.

Zhang, J., Zhang, W., Zou, D., Chen, G., Wan, T., Zhang, M., et al. (2002) Cloning and functional characterization of ACAD-9, a novel member of human acyl-CoA dehydrogenase family. Biochemical and Biophysical Research Communication, 297, 1033-1042. 